\title{
How Aesthetics and Economy Become Conversant in Creative Firms
}

\author{
Austin, Robert D.; Hjorth, Daniel; Hessel, Shannon
}

\author{
Document Version \\ Accepted author manuscript \\ Published in: \\ Organization Studies \\ DOI: \\ $10.1177 / 0170840617736940$ \\ Publication date: \\ 2018 \\ License \\ Unspecified
}

Citation for published version (APA):

Austin, R. D., Hjorth, D., \& Hessel, S. (2018). How Aesthetics and Economy Become Conversant in Creative Firms. Organization Studies, 39(11), 1501-1519. https://doi.org/10.1177/0170840617736940

Link to publication in CBS Research Portal

\section{General rights}

Copyright and moral rights for the publications made accessible in the public portal are retained by the authors and/or other copyright owners and it is a condition of accessing publications that users recognise and abide by the legal requirements associated with these rights.

\section{Take down policy}

If you believe that this document breaches copyright please contact us (research.lib@cbs.dk) providing details, and we will remove access to the work immediately and investigate your claim.

Download date: 26. Apr. 2023

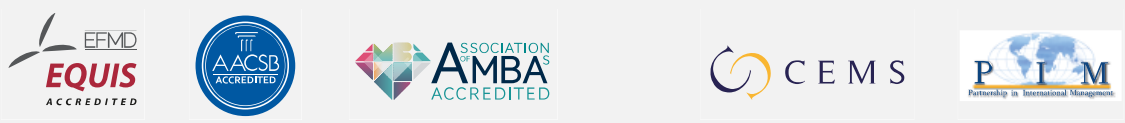




\section{How Aesthetics and Economy Become Conversant in Creative Firms}

\section{Robert D. Austin, Daniel Hjorth, and Shannon Hessel}

Journal article (Accepted manuscript)

CITE: How Aesthetics and Economy Become Conversant in Creative Firms. / Austin, Robert D.;

Hjorth, Daniel; Hessel, Shannon. In: Organization Studies, Vol. 39, No. 11, 11.2018, p. 1501-1519.

Copyright (C) The Author(s) 2017. Reprinted by permission of SAGE Publications.

DOl: https://doi.org/10.1177/0170840617736940

Uploaded to CBS Research Portal: January २०19 


\title{
How aesthetics and economy become conversant in creative firms
}

\author{
Robert Austin \\ Ivey Business School, Canada \\ Daniel Hjorth \\ Copenhagen Business School, Denmark, and Nottingham Business School, the UK \\ Shannon Hessel \\ Copenhagen Business School, Denmark
}

\begin{abstract}
Research on creative organizations often highlights a concern that economic influences on creative work might crowd out aesthetic influences. How this concern can be managed, however, is not well understood. Using a case study of an economic/aesthetic conflict within eTypes, a design firm, we develop theory to describe how the economic and aesthetic can be constructively combined. Building from grounded empirical analysis, we propose the concept of conversation as a way of theorizing about a constructed sociality via which creative firms can manage this conflict. "Converse," according to etymology, means "to live with"; the archaic meaning is "to become occupied or engaged." To say, then, that the economic and aesthetic remained conversant at e-Types through controversy is, we demonstrate, richly descriptive and generative of additional implications. In a similar way, we propose the concept of ensemble - an idea borrowed from the collaborative arts - as a way of theorizing about a conversationally nurtured but fragile form of intensified sociality that is not always achieved, but that most successfully combines conflicting influences when it is. Our findings and theoretical conceptualizations contribute new insights and a framework for organizing a fragmented landscape of ideas about creative work.
\end{abstract}

\section{Keywords}

Conversation, Ensemble, Creative firms, Creative economy, Group creativity, Organizational aesthetics 


\section{Introduction}

We were just like, '[expletive], everyone is making nice design,' so we wanted to make ugly design. - JM, e-Types designer

Research on creative organizations often highlights a concern that "bringing artistic motivation to market runs the risk of weakening or even destroying [the aesthetic component]" (Eikhof \& Haunschild, 2007, p. 538; see also DeFillipi, Grabher, \& Jones, 2007; Glynn, 2000; Hesmondhalgh, 2013; Hesmondalgh \& Baker, 2011; Thompson Jones, \& Warhursts, 2007). What creative firms can do, if anything, to prevent the economic from crowding out the aesthetic in commercial contexts is a matter not yet settled by scholars. Positions range from arguing that economic dominance is close to unavoidable (e.g., Eikhoff \& Haunschild, 2007; Guillet de Monthoux, 2004), to identifying ways the conflict is successfully managed (e.g., Davis \& Scase, 2000; Gotsi, Andriopoulos, Lewis, \& Ingram, 2010). There are significant disagreements (see, Hesmondhalgh's, 2013, harsh critique of Davis \& Scase, 2000, for example). Where there is agreement, the theoretical landscape is fragmented. Caves (2000) argues that creative firms have distinctive characteristics. Thompson et al. (2007) have argued that these differences matter to management and suggested that there is a "missing link" (p. 625) in management theory when it comes to work in creative firms.

In this paper, we describe our effort to address some of the shortcomings of existing theory by taking up the following research question: How can creative organizations successfully manage conflicting economic and aesthetic influences? We focus our study on how employees 
at e-Types, a Copenhagen-based design company, reflected upon and struggled to find a way forward on the occasion of a controversy that threatened the organization's existence. The controversy stemmed from a disagreement between managers and designers about which design should be shown to a high-profile client; managers preferred the design most likely to be accepted by the client, thus most valuable economically; designers preferred another design, which they considered aesthetically superior. The disagreement evoked discussion about "who we are" and "who we want to be," and raised practical questions about how economic and aesthetic considerations influence day-to-day work.

We arrive at findings that describe how e-Types staff cultivates a balanced engagement with economic and aesthetic perspectives, which include sharing commitment to norms of interaction, insisting that no one owns the work and roles are not confining, wanting to maintain conflict, and prioritizing the achievement of unity in outcomes. By inducing them into frequent and familiar association (through interaction, shared ownership, conflict, and pursuit of unity), we suggest that e-Types staff makes economy and aesthetics conversant. "Converse," according to etymology, means "to live with"; the archaic meaning is "to become occupied or engaged." Such engagement, in turn, generates a kind of sociality that members of the organization experience as an important part of their sense of belonging to the group. These findings resonate with a concept, borrowed from the arts, that describes how creative groups conversationally nurture an intensified sociality that is not always 
achieved, but that most successfully combines conflicting influences in creative work when it is achieved: ensemble.

Our concepts of ensemble, and the conversational belonging that fosters it, together constitute a theoretical framework from which nuanced implications about creative work arise. It implies, for example, that an open attitude towards "living with" conflicting influences is more productive than installing safeguards or attempting to resolve the conflict; and that combining conflicting influences constructively cannot be equated to the usual management definition of compromise. In drawing from the arts, we develop theory that we believe might be especially applicable to creative work, reflective of its distinctive characteristics (Caves, 2000). Our contribution, in essence, is to propose concepts that generate insights, and draw together and help organize what has been a dissonant and fragmented landscape of theoretical ideas about creative work.

We organize our paper as follows: First, we describe how current research deals with the management of conflict between economic and aesthetic influences. We then present the research setting and describe the controversy at e-Types that provided the occasion for our study. We follow that with a description of our research approach, including how we analyzed and interpreted our data. We then present our four key findings; and from our findings, we develop and discuss our theoretical concepts and framework, returning to the literature to describe how our findings and framework relate to past research. In a final section, we summarize our conclusions and contributions. 


\section{Managing economic and aesthetic influences in creative firms}

Within research on creative work, firms, and industries, it is not difficult to find evidence of conflict resulting from the divergent perspectives of economic and aesthetic agents. We find, for example, that so-called "creatives" tend to disregard or resist economic, or, indeed, any external motivation (Amabile, 1998) or rationale for justifying their work (Caves, 2000; Florida, 2002). They are described as "non-conformist" (Davis \& Scase, 2000) or rebelling against efforts to direct them towards managerial objectives (Florida, 2002; Sutton, 2001). They "experience constraints imposed in the name of profit accumulation as stressful and/or oppressive and/or disrespectful" (Hesmondhalgh, 2013, p. 70). Indeed, the literature suggests that such resistance, rebellion, stresses, and bad feelings are exceedingly common (Caves, 2000; Christopherson \& Storper, 1989; Davis \& Scase, 2000; Guillet de Monthoux, 2004; Haunschild, 2004; Howkins, 2001; Jeffcutt \& Pratt, 2002; Menger, 1999; Sutton, 2001). And yet attempts to investigate empirically how competing processes aimed at commercial and non-commercial objectives interact in creative firms are few and fragmentary. Thompson et al., (2007) have, in fact, pointed to a "missing link" between "conception and consumption" (p. 625) in understanding of the inner workings of creative firms.

Attempts have been made to address this "missing link." We have already mentioned Eikhof and Haunschild (2007); their study of German theatre companies describes a "central paradox of creative production" 
wherein "economic logics tend to crowd out artistic logics and thus endanger the resources vital to creative production" (p. 523). This happens, they argue, even in settings in which steps have been taken to protect individuals and institutions from economic logics. The theatres they examined were publicly funded and sheltered from market influences by an explicit policy of Kunstfreiheit ("freedom of art" from non-aesthetic pressures). And still, the authors observe, economic influences invariably prevailed. This leads them to conclude that that balancing between the conflicting influences is not enough since this will inevitably lead to a colonizing impact: the economic pushing back the artistic.

Glynn and Lounsbury (2005) suggest that "blending" between economic and aesthetic influences is possible. They come to this conclusion by studying the critical reviews of a symphony orchestra during a conflictridden time when a market orientation began to overtake the once dominant aesthetic orientation of the organization. The blending together process that they describe entails noticeable strife, including a strike, contentious contract negotiations, and the musical director's resignation; not the kind of activities that are likely to be sustainable in daily work. They are also unable to anticipate the effects of this blending on the longterm artistic integrity of the organization; they rather perceive it to be put at risk. Considered together, these papers offer compelling and detailed accounts of how economic and aesthetic influences can combine badly - an outcome predicted or implied by many other authors as well (e.g., Christopherson \& Storper, 1989; Guillet de Monthoux, 2004; Howkins, 
2001; Menger, 1999).

Another category of research focuses on presumed successful efforts to manage tensions in creative work. One approach emphasizes individual roles and identity and suggests that blending conflicting influences is possible at this level. According to Gotsi et al. (2010), during product development processes creative workers experience and manage identity tensions between "artistry" and a "more business-like identity that supports firm performance." They mediate conflicts partly by segregating roles in time and space (“donning 'artist' and 'consultant' hats"), and a "practical artist" self-identity emerges. The authors make use of a "paradox perspective" that helps show how workers reframe tensions, blend seemingly conflicting strategies, and shift the emphasis of managing from control to coping. In adopting paradox as a way of seeing organizational conflict as "two sides of the same coin," (p. 799), Gotsi et al. (2010) are responsive to a call by DeFillipi et al. (2007) for research that moves "beyond either/or thinking" to examine "how organizations and individuals manage to integrate or step around tensions underlying paradoxes or reveal premises as false about how to manage creativity" (p. $516)$.

While Gotsi et al. (2010) focus on roles and identity, Montanari, Scapolan, and Gianecchini (2016) examine the relational processes at work that enable artists to gain organizational support while challenging aesthetic conventions. In a process-oriented case study of a choreographer, they identify "specific relational actions (broadening, bonding, embedding, 
and dis-embedding)" and "how these actions lead to innovation over time" (p. 797). They present a staged model of how the artist oscillates between strong and weak tie relationships with organizations within his network. This study's attention to relational elements and work processes are suggestive of elements of our own study; but its focus on an artist working individually within an extended network toward an artistic (i.e., noncommercial) outcome leaves open questions about the direct applicability of its findings to work in groups within a creative firm.

Perhaps most relevant to our study is the model of "creative synthesis" proposed by Harvey (2014), which, while it does not deal directly with economy and aesthetics, offers one way to understand how conflicting perspectives can successfully combine in group work within a creative firm. Harvey's (2014) concept is based on her study of project groups at Pixar, an animation company driven by commercial as well as artistic objectives. She proposes a dialectical model that explains ways in which conflicting perspectives—art and technology, in this example-can yield creative synthesis in (often interim) outcomes (such as prototypes). Her account makes clear that synthesis that arises in the form of outcomes does not resolve opposing tensions between influences, orientations, and objectives within the organization. These remain in play; indeed, they feature in subsequent examples of outcome syntheses. Harvey's model does not explicitly deal with the tension between economic and aesthetic objectives, but the distinction she makes, between tactical syntheses in outcomes, which happens repeatedly, and resolution of the 
ongoing tensions between conflicting influences, which does not happen, appears to us important to developing a more nuanced understanding how conflicting influences combine in creative work (we will echo and elaborate upon these elements in our own findings and theorizing).

There is also research on managing conflicting objectives in day-today work that, although not specific to creative firms, veers close to our topic in this paper and suggests that these influences may be productively combined or balanced. Reay and Hinings (2009) describe conflicts between physicians' concerns about medical outcomes and healthcare managers' concerns for efficiency; they suggest "pragmatic collaboration" as a way of combining the two. Through pragmatic collaboration, physicians and managers are shown to resist the expectation that temporary difficulties of managing multiple influences on work will be resolved in a way that diminishes the importance of one, either through competition, or by one influence dominating the other (Reay \& Hinings, 2009, p. 631, citing Hensemans, 2003 and Hoffman, 1999). Similarly, Austin and Nolan (2007) focus on high tech settings where managers try to optimize business value and workers are motivated to solve technical problems, for their own sake or to impress peers. They suggest that "balance" is possible and offer advice: Let each camp win now and then; require workers to regularly produce tangible artifacts, and orchestrate regular engagement around these artifacts; also, cultivate "bridging personalities," people capable of understanding both perspectives and mediating between them. In both of these settings, the parties are able to work together without compromising 
their distinct professional identities. While studies like these generate advice for allowing open dialogue between people who hold conflicting values and beliefs, we cannot be confident that their recommendations extend to creative work; they describe cooperation born of necessity, motivated by the desire to accomplish difficult, well-defined goals, rather than a form of collaboration more common in creative processes that aims to generate valuable novelty (Austin \& Devin, 2003; O’Donnell \& Devin, 2012).

There is also research that takes up questions of conflicting influences at the organizational level. Davis and Scase (2000) describe an evolution in the late $20^{\text {th }}$ century when creativity-driven organizations were bought or came under market pressures in other ways, which led creative work to be situated increasingly within profit-oriented commercial bureaucracies. When this did not work (because it caused economic influences to crowd out aesthetics, undermining creative capabilities), creative workers were then organized into smaller, more autonomous units more like subsidiary companies. Hesmondhalgh (2013), however, calls this analysis "flawed" (p. 192) and takes issue with both its historical narrative and causal analysis. For our purposes, the specifics of this disagreement are less important than the observation that it rarely reaches down to the level of daily work processes. A general management literature on "ambidexterity" (e.g., O’Reilly \& Tushman, 2004, 2008), about managing conflicting between "exploration" (seeking out new ways to create value) and "exploitation" (creating value by applying already 
known methods; see March, 1991) has a similar focus at the organizational, rather than process, level.

If we consider, in overview, the research on work in creative firms, specifically the issue of how they manage tensions between economic and aesthetic influences, we can identify important contributions. Ideas like practical artistry and role segregation (Gotsi et al. 2010) are helpful on their own and seem corroborated by thematically related ideas like ambidexterity and pragmatic collaboration (Reay \& Hinings, 2009). The apparent similarities in these ideas seem suggestive of broader concepts, but the linkages remain undefined, the ideas relatively freestanding. In places, theoretical notions seem contradictory: Eikhof and Haunschild (2007) predict inevitable dominance of economic over aesthetic, while Glynn and Lounsbury (2005) suggest blending is possible, and Harvey (2014) describes an instance of how dominance of one influence over another is avoided (at Pixar). Currently, we lack concepts or frameworks to help tie the disparate ideas together and explain the apparent contradictions. It is this theoretical deficit that motivates our study.

\section{Research setting}

At the time of our study (10 years after founding), e-Types had evolved into a full-fledged brand agency, capable of designing identities and formulating full-blown marketing strategies. A partnership with four principals and about 30 employees, the company hired business school graduates to work alongside designers, to integrate parts of each client's 
identity in a way that differentiated the client from competitors. Clients included Carlsberg Breweries, Levi-Strauss, and other prominent international companies.

Partners participated full time in daily work, carried equal status, and made decisions jointly. Employees included designers, technical assistants, brand strategists, researchers, and administrators. Reporting structure was informal; employees turned to different partners for assistance depending on individual inclinations. Employees with business training tended to consult the managing director; designers tended to go to creative directors.

Usually e-Types billed by the hour, but it occasionally accepted fixed-price terms; working within client specified budgets was the norm. Pricing considered the value of the services being provided, the attractiveness of the client (reference-ability, ability to pay), and how far a project might stretch the firm. e-Types also entered competitions - risky because they cost as much as a contracted job but did not guarantee recovery of expenses. Competitions were, then, a form of marketing; the firm could gain fame by winning. Overall, costs were mostly fixed: salaries, materials, rent. Revenues were more variable, but as long as the incoming workflow remained adequate, e-Types made a profit. At the time of our study, e-Types was quite profitable.

e-Types had always embraced a rebellious sensibility. The firm's statements of principles recommended, "mess[ing] with" clients and "smashing the [design] world." Designers, especially, embraced an ethos of 
"edginess." Concern for this aspect of the firm's culture came forcefully to life when its involvement in a competition erupted into an internal controversy.

\section{The Team Danmark controversy}

When Team Danmark (TD), Denmark's international sports organization, asked three firms for proposals to redesign the team's public identity, eTypes was delighted to be included. The competition offered less than ideal ground rules, however. The timeline was short. Competitors would work from a "brief," a thin document that contained mostly visual guidance, not the rich background on strategy, goals, and thematic factors that e-Types staff preferred. Also, the TD brief was conservative, a poor fit with the rebellious inclinations at e-Types.

Working from the brief, e-Types designers quickly developed a strong first proposal. But there was a problem: Key designers, including the creative director most responsible for the design, considered it "boring." A little later, designers produced an alternative "edgy" design that they greatly preferred. But managers and strategists raised questions about the edgy design. Would TD accept it? "It's the one we like," they argued, "not the one they want...how selfish do we want to be?" Everyone, including designers, agreed that this design was much less likely to win the competition. But designers "hated" the first design ("It's so bad...we shouldn't show it to anybody"); they thought it represented a betrayal of the firm's rebellious founding purpose. Creative director JH captured the 
sentiments of many designers when he said, "It's like the medieval knights and all - it's not about the money, it's your honor."

In the end, e-Types presented only the edgy design. And, as expected, they lost. Employees mostly came together around this decision, interpreting it as re-asserting who they wanted to be as a firm. At the time, e-Types was flush with cash, so the loss had little immediate financial consequence.

\section{Research approach}

The e-Types case was developed using accepted approaches for developing theory from analysis of cases (Glasser, 1978; Miles \& Huberman, 1994; Strauss \& Corbin, 1998; Yin, 1984). Although this study was part of a larger study that involved many cases, we singled out this case for closer examination because the controversy at e-Types presented an opportunity unique within our data set to address an understudied issue that we considered important. The in-depth, single case study is generally considered an appropriate approach for inductive refinement of existing theories in areas where there are gaps, contradictions, or apparent inconsistencies (Edmondson \& McManus, 2007).

Three investigators, working sometimes together and sometimes separately, interacted with firm employees in a variety of ways with the specific intention of accessing the day-to-day life of the firm from multiple perspectives. Our interactions included seven in-depth individual interviews (one to two hours) with key players in the firm, including three 
of the four principals, two designers, and two strategists, and a multi-hour group interview about the firm's business (how it charges clients, how it manages its finances, et cetera) with a mixed business/designer group. Five interviews were "template" interviews, which employed a semistructured approach developed for the larger study aimed at accessing the details of "making processes" within creative and, for comparison, notprincipally-creative firms. The remaining interviews were less structured "context interviews," aimed at obtaining a detailed understanding of the firm's business, industry, and operational surroundings helpful in interpreting template interviews and data obtained from observation and examination of documents and other work products. All interviews were video recorded.

On multiple occasions, we observed staff at work, including working meetings, making efforts to be unobtrusive (but unable, of course, to be invisible). We observed, for example, a design review meeting, in which designers shared information about projects in process and received feedback from management and each another, both about design content and resource allocation issues. In addition, we examined work products, documents, prototypes, and final designs. We spent hours with staff talking about the portfolio of work they had done in the past, the processes for working on those jobs, and the difficulties and discussions that had arisen on each. When video recording was not practical (in working meetings, for example), we took detailed field notes. We followed up with additional informal interviews via telephone to fill in details we had 
missed in primary data gathering, and subsequently attended firmsponsored events, and interacted with firm principals when they were guests in our classrooms. In generating data in a variety of ways, we sought to triangulate observations and interpretations, to corroborate findings, prevent premature closure, and strengthen confidence in our empirical grounding (Rothbauer, 2008).

An unusual element of our empirical approach was a multi-hour group interview about the TD controversy, during which we intentionally facilitated a resumption of a conversation that had happened about one year earlier. This "re-staging" caused participants not only to restate earlier positions, but also to re-engage in active debate, presenting different viewpoints with energy and passion. It was apparent that a general form of this conversation within e-Types, which focused on questions of primary interest to our research, remained active, and that our group interview technique caused it to re-manifest, with startling freshness.

While methodological concerns could be raised about retrospective and other biases that might influence recall about the events that surrounded the TD controversy, we suggest rather that this session provided us some of our best access to the phenomenon that we most wished to observe: The informants' ongoing, dialogical reconstruction of patterns of generative sociability within which they attempted to navigate economic/aesthetic conflict. Informant interaction in this setting prompted resumption of a general conversation about "who we are" as a firm, in 
which individuals debated issues of relative priorities (e.g., hitting deadlines versus pursuit of aesthetic greatness) and discussed different areas in which they sought balance, but had different ideas about what that meant and how to achieve it. It was not difficult to restart these conversations, or to recognize them as recurrent in the life of the firm.

\section{Data analysis}

We analyzed our data using an extension of the approach we had developed in the larger, multi-case study, in which we used grounded theory coding (open, axial, and selective; Boehm, 2008) to identify and capture concepts, relationships, and descriptions within the work process of individuals engaged in joint work. Important conceptual categories that emerged from the larger study included attitudes and beliefs exhibited within a work setting (e.g., openness, to others, both customers and coworkers, and also to random variation and other contextual factors; concern for cost, outcome differentiation, or economic trade-offs), behaviors (e.g., ways of collaborating or asserting leadership, tendencies to defer based on specialization), norms of interpretation (e.g., how "failure" tended to be conceptualized, what counted as "failure"), outcome characteristics (e.g. variety, novelty of outcomes), and process factors (amount of repetition, design for experimentation, planning intensity). These categories allowed us to group cases into clusters within which we found shared patterns of concerns. In one cluster, firms exhibited particular concern with managing economic/aesthetic conflicts. We chose 
e-Types, a case within that cluster, to drill down into this issue, because the controversy at e-Types seemed likely, we thought, to provide particularly rich and relevant data.

Analysis of the e-Types case made use of a second order approach that paralleled the approach in the broader study, using open, axial, and selective coding, but with a focus on the issue of economic/aesthetic tradeoffs, within the context of broader conceptual categories already established in the larger study. That is, we knew some things already about how e-Types did its work, from the earlier round of analysis, but this second round yielded additional concepts, relationships, and descriptions relevant to our new area of focus. Transcriptions and other documents assembled in the first round served also as a basis for second round analysis. We took an iterative approach, visiting and revisiting data sources, and oscillating between coding and a broader perspective that helped us extract additional interpretations.

In formal coding, empirical material was examined independently by multiple analysts. We checked interpretations for consistency between analysts and employed precautions to assure that resolution of inconsistencies was based on valid re-interpretations, not merely a desire for agreement. Video recordings made it possible to revisit the interviews, and we did this sometimes (Heath, Hindmarsh, \& Luff, 2010).

Our empirical analyses of the case, with supporting documents, had been gathered into a 112 page "case treatment" in the larger study; this included field notes, photographs, and such other data sources as could be 
practically appended. Our team of three researchers studied the case treatment and engaged in a systematic examination of the document, identifying major elements of the "story" the data was telling (Boehm, 2008) about how work was done within e-Types, and discussing aspects relevant to our focal issue in considerable detail, to interpret and develop consensus on the findings that emerged.

\section{Interpretation}

In our final stage of analysis, we made efforts to reach beyond what we could strictly derive from the empirical findings, to arrive at richer and more expansive theoretical conceptualizations. We acknowledge here an act of interpretive creativity. Whereas our findings intentionally remain close to the phenomena, and express concepts, relationships, and descriptions in the interview subjects' terms, our conceptual interpretations arise from our efforts to conceive descriptive metaphors or analogies. Thus, for example, our interview subjects never used the word “ensemble," which we will propose as richly descriptive, nonetheless, of what we observed at e-Types.

In so doing, we work in a constructionist-processual tradition where the metaphorical function of theoretical concepts is central (Morgan, 1980). Concepts are metaphorical as they bridge conceptual correspondences (Lakoff, 1993). They enable us to see one thing as another (ontological correspondence) so as to make knowledge of one thing available to knowing another (epistemic correspondence). Suddaby, in 
clarifying what "construct clarity" is, defines constructs as "conceptual abstractions of phenomena that cannot be directly observed." (2010, p. 346). In this line of reasoning, constructs are the foundation of theory, when the latter is defined as a system of constructs. Suddaby acknowledges also that constructs "...are the outcome of a semantic network of conceptual connections to other prior constructs" (2010, p. 350), with reference to systems of signification.

Concepts have explanatory power in certain domains but are always related—through the metaphorical nature of language and knowledge—to an endless series of other conceptual domains. Concepts, for most nonpositivists, are embodiments of knowledge and what we use when we think, which is a practice in the world. The purpose with using concepts in a new domain (of practice) is, therefore, to acquire new levels of precision and new avenues for describing and acting in that domain. Showing how concepts from one domain metaphorically can correspond to concepts in another domain will construct new and further correspondences to previously unrelated and/or poorly related domains of practices.

Thus, when we use the concept of ensemble in this article, we do this in order to more precisely describe how one concept from the domain of performing arts corresponds to the domain of creative companies. This, in turn, makes it possible to think and practice differently in contexts of such companies (and perhaps beyond). In this way, theorizing proposes developments of thinking (and by implication, practice) using new conceptual relationships made possible. 


\section{Findings}

Employees at e-Types, regardless of their role, spoke favorably of the distinctive elements of the company's culture and approach, and often talked in terms of an "e-Types Way" of doing things (e.g., AT: "I think we have, more or less, an e-Types way of doing it"). Our efforts to understand the e-Types Way yielded four specific findings:

\section{Shared commitment to norms of interaction}

A prominent feature of this "way," which employees seemed quite pleased with and proud of, was the very dialogical nature of daily interactions at eTypes - how they involved close and frequent association between different people, viewpoints, and methods. We heard, again and again, about the importance of conversational interaction within the e-Types way of working. JM (a designer) said:

It is important to me to have one person here and one person there...somebody who is close to you that you can always ask for something or [ask] "how do I do this?" Or to have conversation... You can always shout through the room, "hey how about that?" Different projects, different people, and you can easily communicate, but you can also always easily interrupt people...

Employees considered this kind of conversational interactivity to be a distinctive feature of work at e-Types, not something that you would encounter readily at other firms. JA, a designer who had relatively recently joined e-Types and had worked at other firms, commented explicitly on how interaction norms at e-Types seemed different and 
better:

I think it is really nice to have other people to work with and share the work process with...that is how it is working here. And by being a lot of people working together, I had to see my work in a lot of ways, and when you're working together you comment on each other's work and then you develop a lot quicker...that was just [what I] needed [at the time when I joined e-Types].

Interactions went beyond mere words, however. Proposals developed from individual work were compared and adjusted to each other, repeatedly. AK (a project manager and strategist) described this process:

We think it's quite natural if people say what they feel about things and then I can go back...and think, "Ok, I had that input and I have to change direction." It's quite helpful. Often people do it instantly if they pass a computer and say, "Oh this looks nice"... So there's this unstructured communication.

People highlighted the importance, within this iterative process, of interaction between business and designer viewpoints. AT (a strategist) gave an example:

In the explore/research phase...the designers are very often part of it...very often they attend the interviews and go visit the client, take a look to get their ideas...at the same time as I am working with the idea on the strategic level, they are working in their head with the idea at the design level...I check what the designer says, that [my evolving sense of brand essence] matches with what they perceived...It's important that...they don't feel as if what was made in the strategic phase doesn't fit with what they are going to do afterwards.

Employees took great care to ensure along the process that strategic and design work developed from a "matching" understanding of the idea. 
This concern that strategy and design develop in parallel points out another norm of interaction that was easy for us to notice: an insistence on parity of status between business and designer viewpoints. Managing Director SO firmly expressed his determination not to let one viewpoint dominate:

We do it all at once [i.e., together]. That's important. We're not two companies or departments but a lot of professionals working with a corporate identity. Either side might lead. We try to have an integrated approach.

One behavior we observed that seemed reinforcing of the norm of status parity was a self-conscious tendency of e-Types employees to voice each other's concerns about work objectives and processes. So, for example, creative director $\mathrm{JH}$, without being prompted, strongly endorsed the need to be client-oriented: "I'm not an artist. I'm a designer. I work for a client." Conversely, the firm's business staff often voiced the need to push clients, to move them in challenging, even unpalatable directions. "[Clients] shouldn't feel relaxed in [an identity developed by e-Types...]," said SO; "You can make a 'no-surprises' identity, but then you have no inspiration." It seemed widely accepted, and was often said, by business staff members, that sometimes profits had to be sacrificed to maintain "quality." Even AT, the strategist who seemed most inclined to economic arguments, made a point of voicing designer-like sentiments: "Sometimes [clients] want something we think is wrong for them...If they want to be too safe, we very often try to take them one step further."

Such statements appeared to function as more than explanations. It seemed to us that they were also declarations of commitment to the e- 
Types way of working, especially its norms, and perhaps assertions of how special it was, and how pleased employees were to be part of it.

2. Shared insistence that no one owns work and roles not be confining

e-Types staff members expressed an aversion to the idea that any individual employee "owned" any aspect of the work; they also rejected the idea that employees should stick to their roles. Creative Director JH stated:

It's very important to be open about your work, because it's not yours at all. You have to come up with the best idea. You have to ask for help...All are free to come up with everything. If we separate roles, it gets to be a factory. I think if you are educated another way you have ideas as well as I do, so everybody is welcome to join in.

Employees believed that this attitude toward roles was a distinctive element of work at e-Types:

I came here because I want to work with a broader perspective of design involving other people than just designers...It is not like you can only say something about the visual if you're a designer. Everybody can say something about it. And everyone can say something about strategy. (JM, designer)

Managing Director SO stated that roles should not be confining as an e-

Types management policy:

We think very much in terms that consultants working with concepts should also work visually and communicate at more levels, not just words and concepts, but also find images. At same time those trained as designers should over time be trained more and more as consultants also...[Y] ou don't split the company with some people taking care of creativity and some people taking care of money. You have to get both logics to respect each other. Without both of them we aren't a company. 
It was clear, also, from our interviews, that this ethos of aversion to individual ownership and openness to commentary regardless of roles extended even to strongly critical comments. AK put it this way: "We have a good atmosphere here where people can be nice to each other, but very honest...if we cover up [i.e. protect] ourselves then the project [is] maybe going in the wrong direction." Asked if critical comments ever became harmful, JM said, "Nah, I don't think so...people should say what they think, and if they think that it doesn't work or it looks like shit, then they should say it." An implication of no one owning the work seemed to be that the work could be subjected at any time to harsh critique. And because roles were not considered confining, that critique could come from anyone. Designers could criticize strategy, and strategists could criticize design.

Dismissing the idea of individual ownership also meant dismissing the idea that any individual controlled outcomes. No single person had final say on a project outcome. SO explained: "You have to come up with good arguments; and what [the group] decides, you do."

\section{Shared desire to maintain conflict}

By insisting both that differing viewpoints had to be heard and that interactions had to be honest, the e-Types way of working more or less guaranteed conflict. Conflicts ranged from professional disagreements over whether to put more time into an over budget project, to more general debates about what kinds of projects the firm should be taking on, and occasionally, to more major disruptions such as an exodus of some 
partners that forced the company to reorganize (a few years before the TD controversy). It was clear from our observations that it was not the way within e-Types to try to minimize or avoid conflict, or to reduce the discomfort of participants whose views were at odds.

In fact, e-Types employees, and especially partners, spoke favorably of episodes of conflict (which they referred to as "dramas"). Partner RI, a founder, was trained as a designer but had gravitated over the years to a management role. In our analysis, we identified him as the person most focused on setting a good climate for long-term well-being of the firm. His thoughts about conflict were especially interesting:

We need some kind of drama...it always gives us an opportunity to do something new. To maybe be forced to change the way we work...Drama is part of what keeps you on edge...We need to take chances, challenge the way we do our work.

Not only did RI and his partners value drama or disruption of their usual ways of working, but they sought it out, for example, by hiring designers who challenged their aesthetic.

Further, e-Types partners made efforts to maintain conditions that kept conflicting factors present within working process and to seek balance between them. In particular, they took actions to make sure aesthetic influences remained present. "If you are going to be a really great creative company," said SO, "you have to have a certain amount of cash flow so you will be able to afford to say 'no' [to jobs that required setting aside aesthetics in favor of economics]." This allowed e-Types, he explained, to "take the decision to do what we believed in based on what 
we felt was right for design style, a little bit what was right for the client, and in the end for what kind of company we want to be-a company that challenges our clients." RI made an even stronger statement about the need to turn away from work that did not fit with the firm's multi-voiced process: "It's important that in these successful times we dare to turn people down to use our efforts on the right clients." For RI, management monitoring of the e-Types way of working was centrally about maintaining the presence of aesthetic influences within the business context:

\begin{abstract}
Sometimes you have to forget the structure and the money ...Even if [Managing Director SO] says in a meeting every week "this project is good or that project is bad, because of money or hours," [designers] won't care because this is not their motivation. We have to have a balance between the people inspiring the company and [the people] being true to the professional company that needs to earn money. I see myself as one who has to preach this religion. I fully agree with [SO], I'm just trying constantly to find balance.
\end{abstract}

\title{
4. Shared belief in the importance of unity of outcomes
}

The choices and behaviors of e-Types employees on the occasion of the TD controversy and in its aftermath revealed a shared concern with achieving a kind of unity of outcomes that integrates conflicting economic and aesthetic concerns. As we have mentioned, after extensive discussion with staff, e-Types partners agreed to show the client only the edgy TD design, even though they thought it would probably not win the competition. As SO put it, "we wouldn't really have liked them to choose it." And, as expected, they lost. Interestingly, though, in our interviews most e-Types staff members clearly saw resolution of the TD controversy as a moment of triumph for the firm. It expressed a renewed commitment to keeping 
aesthetic concerns present, and to a multi-voiced process. SO described the immediate aftermath: "After the closure was made everyone was feeling 'Wow, we really say 'No' and we're standing up for what we believe in.' So this is actually quite a good feeling. 'Though we lose, we know we've done the right thing."

The resulting feeling of unity, both in internal purpose and outcomes, appeared to be something e-Types staff recognized as a signal that they were maintaining their successful ways. The decision to present the edgy design was, they argued, fundamentally coherent and consistent with their objectives of being a highly differentiated, high margin player in the design company space. As JH explained: "Maybe we do a bad design and get money, but we don't get the next client. You have to think in long terms." Indeed, in the months following resolution of the TD controversy, e-Types attracted two large, conservative clients, both with big budgets and strong payment track records, who came looking for edgy work, the kind of work e-Types was best at and most wanted to do. SO's conclusion from this: "We don't have to sell out to move up in market—[if we had] we would have been a less interesting design company."

In still later months, e-Types's again demonstrated their commitment to unity in outcomes when confronted with another difficult situation. The difficulty arose with a client that had been the single largest source of e-Types revenues in the previous year. This client proposed individual tweaks and isolated changes, which had been suggested by the company's marketing department, to an e-Types design. 
Emboldened by the TD experience, and reassured of the rightness of their commitment to unity of outcomes, designers refused to make these changes, arguing that changes made in isolation destroyed the overall unity of the concept. In essence, the changes, if agreed to, would have sacrificed aesthetics for economics. When the client insisted that e-Types make at least some of the changes, as a sort of compromise, to placate the client's marketing department, e-Types refused and responded by "firing the client." Like the decision in the TD case, this decision met with widespread approval from e-Types staff members.

\section{Developing theoretical concepts from findings}

To lend form to the theoretical refinements that are the objective of this study, we have developed two concepts to illuminate and give added meaning to our findings.

\section{Conversation}

We propose conversation to describe a way of dialogically relating conflicting concerns in creative companies, consistent with our first finding. "Converse," according to etymology, means "to live with"; from the Latin conversationem, "the act of living with," the archaic meaning is tied to acquaintance and familiarity; even today the word includes this meaning: "to become occupied or engaged" (Merriam-Webster, 2017). Our observation, summarized especially in our first finding, that the e-Types way was extremely dialogical, revealed extensive conversational 
interaction, much of it actual verbal communication. Our focus here, however, is on the larger, "living with" sense of the word; as we have noted, work processes at e-Types proceeded iteratively, in a manner that placed viewpoints, proposals from individual work, strategies and prototype designs in frequent and familiar association. We observed concerted efforts by staff members to remain engaged with each other (JA: "when you're working together you comment on each other's work"), and to maintain multiple voices, including conflicting voices (our third finding), in close juxtaposition. This ongoing form of nurtured sociality seemed to provide a helpful context for both tactical activities aimed at producing periodic interim outcomes (e.g., proposals, prototypes) and a persistent organizational capability for managing conflicting influences.

We understand conversation, for such contexts as this, to be a form of belonging that undermines principles and practices of management that might otherwise reproduce the dominance of the economic perspective in organizational contexts. Belonging describes the opening to the other and to what they were not but could become in conversational interaction (Massumi, 2002). It was not so much about individual staff members identifying with the organization as it was an affirmation of the idea that any future collective identity would always come from a generative relation in between members, a 'living with'. The tendency we observed of e-Types staff members to frequently voice each other's concerns can be seen as a statement of belonging - a demonstration of a dialogical "with"ness meant to reassure other participants in work processes of the 
speaker's genuine efforts to achieve conversation and to avoid dominance of one influence over the other.

Conversation is always an achievement in the context of organizational realities due to them necessarily including competing rationales (Townley, 2002). The monologic, dictating relationship is more often the communicative default because, as Bakhtin asserted, classical logic - built into traditional organizational structures via hierarchy - is bivalent, admits only either-or, true or false (DeSantis, 2001). What we recognize in the example of e-Types, and mean to emphasize is that the bivalent, monological and dictating tendencies have to actively be warded off, so that the meeting of perspectives instead results in multi-voiced dialogue rather than silencing (cf. Steyaert, Bouwen, \& Van Looy, 1996). As Managing Director SO insists, 'You can't give your partners orders. You have to come up with good arguments, and what they decide you do." Management needs to sometimes say "No" to a potentially lucrative job from a big client, as hard as that is to do, in order to avoid compromising their aesthetic values. Dramas, like the TD controversy, appeal because they incite this active warding off; they provide repeated opportunities to practice it and to reassure workers of the ongoing commitment to this warding off. We characterize the achievement of these conversations as a struggle due to our understanding of the structural order of knowledge (and corresponding professional identities/roles) in contexts of business organizations. The prerogative of management and the subsequent domination of a managerial rationale (rationale, defined here in Weberian 
terms as what is sound judgment in the context of a specific value sphere; Townley, 2002) make it necessary to actively breach this order so that a multi-voiced, conversationally established belonging can emerge.

Conversational belonging, or "living with", can thus be described as an achieved sociality, one that involves risk-taking and being responsive (JM: "[if] it looks like shit, then they should say it"). Our concept of conversation has, therefore, more in common with dialogic approaches in social theory. A central thinker who sensitizes us to dialogical interaction is Bakhtin (Bakhtin \& Holquist, 1981). From Bakhtin and Levinas we learn that it takes generosity and courage to invest in a conversation (Poulos, 2008). We find evidence of such generosity and courage in the "eTypes way", which allows for conflicting perspectives to co-exist, and for staff to engage in substantial shared investments in conversation. The "living with" of conversation requires the kind of generosity that characterizes openness to others and acceptance of the other's otherness (Levinas, 1981): strategist accepts designer, designer accepts strategist, which both demonstrate regularly by voicing each other's concerns. This generosity makes it possible to "agree" and "accept" the contributions of others in dialogue and improvisation and then exercise courage when "adding to" these contributions with your own (Johnstone,1979). These acts are considered critical to many group creative processes (O’Donnell \& Devin, 2012).

\section{Ensemble}


The second concept we propose as a contribution to the theory of managing conflicting economic and aesthetic influences in creative firms is borrowed from the world of performing arts: ensemble. Although the word is sometimes used generically to refer to a group of players, such as actors or musicians, we are more interested in the use of the word, also common, as a desired, enhanced state of collaboration that a group of players strives to and sometimes does achieve. Of a group of players who practice together and are successful in combining their voices into a coherent whole, we may say that "they have become an ensemble."

Austin and Devin (2003), describing the work of theatre performers, suggest that creative socialities happen through iterative processes of individual preparation and collaborative exploration. They describe ensemble as "[T] he quality exhibited by the work of a group dedicated to collaboration in which individual members relinquish sovereignty over their work and thus create something none could have made alone..." (p. 16). In a practical illustration of how ensemble might come into being, they describe preparations for Shakespeare's Hamlet:

In George's solo preparation of Hamlet, he assumed a quiet, shy Ophelia...When they meet at the table, the first thing George notices is that Emily [playing Ophelia] isn't shy at all...He's soon astonished to discover ...that she intends to play Ophelia in a bold, in-your-face manner...As an ensemble member, George doesn't get to put up his hand and say 'I'm sorry, but that's not how I see Ophelia; please change according to my ideas.' Instead, George's professional duty is clear the must reconceive what he's doing to include Emily's work as part of his own] (p. 103).

As a result of working in this way, participants "reconceive what they're doing to include the other's work..." (p. 103; italics in original). When 
ensemble is achieved, the outcome of the work exhibits a sense of unity, a certain "aesthetic coherence" (Austin, 2008).

We see evidence of striving for ensemble in the work at e-Types. The insistence at e-Types that no one owns the work, as described in our second finding, can be construed as an example of "relinquishing sovereignty" over the work. Insistence that differing viewpoints should be considered legitimate and accepted, regardless of who they come from (JM: "people should say what they think") and that proposals should be adjusted to each other (AK: "ok, I had that input and I have to change direction") would seem to describe a process of reconceiving. The fact that no attempt is made to resolve or lessen conflicting influences, or to grant one precedence over the other - rather the opposite, there are efforts to keep conflicting influences present and equally in status - reminds us of the way George needs to include Emily's work in his own, without obliging her to conform. Also, that workers at e-Types revere and aspire to unity of outcome maps well to the idea of aesthetic coherence as an outcome of ensemble. The dialogically created outcome is a new whole that is neither "mine" nor "yours" but has overcome such appropriation of strands in bringing participants into the different new (Bakhtin, 1986).

Ensemble, like conversation, is an achievement—one that depends on conversation to emerge and is made fragile by its dependency. Conversation can strengthen a sense of belonging to the extent that an ensemble emerges. An ensemble, then, is a conversationally intensified sociality that prepares a space for collaborative creativity (Hjorth, 2005). 
As a conversationally intensified sociality, ensemble is also fragile in that it depends on the generosity and courage of participants to play along and relies on their willingness to struggle (actively ward off dominating forces) to maintain an openness to others and to others' potentiality in order to achieve unity. Otherwise, the conversational belonging that sustains ensemble can collapse into individual performances that, although possibly coordinated, will struggle with negative tensions (based on professional identities: Glynn, 2000; divergent work ethoses: Grabher, 2002; conflicting logics of practice: Eikhof \& Haunschild, 2007; or rationales: Townley, 2002).

\section{Discussion}

Comparison can be made between our results and similar research that specifically addresses the creative industries to suggest extensions to theory. It could be said that our work here describes the "blending" of Glynn and Lounsbury (2005) in greater detail, though they mostly describe a situation that appears dysfunctional. We are at odds with Eikhof and Haunschild (2007), who argue that the economic inevitably colonizes and endangers the aesthetic; indeed, via our study of e-Types, we have been specifically seeking to understand how an exception to their "paradox of creative production" might come into being. And though we are attracted to Gotsi et al.'s (2010) use of paradox as a way of seeing organizational conflict as "two sides of the same coin" (p. 799), and rejection of either/or thinking (DeFillipi et al., 2007), we saw little 
evidence at e-Types that designers experienced identity tension between "artistry" and "a more business-like identity that supports firm performance"; rather, roles were fluid, no one owned the work, comments about anything could come from anyone, and there was shared belief in the legitimacy and necessity of differing viewpoints. Tensions existed between economic and aesthetic influences, but the commitment to conversational belonging, to courage and generosity, focused participants on the in-between, the "with", rather than on individual identities. This explains why we, at e-Types, saw no examples of segregating roles in time or space (quite the opposite, in fact), or of any behavior so demarcated that it could be construed as donning different "hats."

Our findings and subsequent interpretations and theorizing extend most naturally, we believe, from elements of Montanari et al. (2016) and much of Harvey (2014). Montanari et al.'s emphasis on relational factors has clear common elements with our own approach, though we also differ with them in some ways (which we will describe below). Harvey emphasizes how the conflicting influences (art and technology) are kept in tension within the Pixar process; she discusses as well how these conflicting influences combine successfully in outcomes, but are not resolved; rather they continue to drive the creative process forward. We would describe the process Harvey describes as "conversational" and suggest that the successful combining she reports might have arisen from the attainment of ensemble.

Other general (i.e., not specific to creative industries) theories align 
to some degree with ours. Though we would concede that there is an element of pragmatism in the way of working at e-Types that is evocative of the "pragmatic collaboration" of Reay and Hinings (2009), or the "practical artistry" of Gotsi et al. (2010), we respectfully suggest that this emphasis on the "pragmatic" and "practical" directs attention to the least remarkable aspect of what we observed at e-Types. What was most remarkable, to us, was how strongly present non-pragmatic influences remained within work processes. We find it easier to agree with Austin and Nolan's (2007) recommendations of "balance," letting both "sides" win sometimes, and orchestrating ongoing engagement around prototypes; at e-Types, RI was arguably an example of what they call a "bridging personality."

The advantages of a theory specific to creative work

We believe that it is a strength of our approach that we explicitly take into account the distinctive features of creative work in developing our theoretical framework, and that we intentionally draw inspiration for our theorizing from the realm of the arts. We suggest, conversely, that certain weaknesses in existing research derive specifically from their inclination to do the opposite: to apply (we might say "shoe-horn in") more general management thinking in a creative context. Because management thinking has traditionally been oriented toward the rational and analytical (Strati, 1999), it has trouble describing certain elements of creative work. From within the perspectives of many approaches to 
organizational analysis, conflicting influences need to be resolved, perhaps by one prevailing over the other (Eikhof \& Haunschild, 2007). Tensions lead to a need to be "pragmatic" (Reay \& Hining, 2009) and to "cope" (Gotsi et al., 2010) with a situation that is implied to be out of the ordinarily desirable state of affairs. Within this frame, attitudes and behaviors must be segregated conceptually into discrete categories; different "hats" must be donned (Gotsi et al., 2010); relational actions must be analytically decomposed ("broadening, bonding, embedding, disembedding", Montanari et al., 2016). Individuals oscillate between states because they cannot be in both at once, and more desirable states can be restored through compromise.

Framing concepts adopted from the arts, however, have the potential to be more holistic and to provide more nuanced descriptions and understanding. To include another's work as part of our own, in belonging, is very different from compromise, which resolves conflict by modifying (usually, reducing) one's own objective in order to allow that the other might also attempt to realize a diminished version of his or her objective. "Other" and "own" are overcome in ensemble. Rather than the production of what should come, according to pre-specified expectations, we see at eTypes an openness to what could come (Hjorth, 2012). Without an aesthetically inspired theory specific to creative work, we are left primarily with compromise and coping to "resolve" conflicting influences.

A theory of creative work should invite us to take seriously concerns about the coherence of outcomes that combine conflicting influences and 
the perhaps fragile states that produce these. A theory of creative work based on conversation and ensemble invites us, for example, to consider when and whether ensemble was successfully attained. We submit that eTypes did not achieve ensemble in the creative process of generating designs for the TD competition, but that they did achieve ensemble in their efforts to decide which design to present. Interviewing them about this event caused them to perform ensemble work as they reflected on what had happened. Enabled by conversation, conflicting intentions were reconceived and combined to yield an outcome that was both exhilarating for participants (SO: "this is actually quite a good feeling") and perceived as effective in the broader terms of the firm's overall strategy (RI: "we could take the decision to do what we believed in based on... what kind of company we want to be-a company that challenges our clients").

But the fact that two conflicting designs remained at the end of the creative process suggests that in the design process itself, conflicting intentions were never reconceived and combined. In the terms of the earlier cited Hamlet example, the e-Types creative team continued, until the end of the TD design process, to say to one another the equivalent of "I'm sorry, but that's not how I see Ophelia; please change according to my ideas." In our interviews, subjects expressed this idea saying that the design process had "stopped too soon" on the TD job. They tried to imagine ways in which they could show both designs to TD in order to initiate a new process, in closer conversation with the client, to come up with a better outcome where intentions could be combined. 


\section{Conclusion}

We have shown that economy and aesthetics can become conversant in creative organizations. When firms create generously open socialities, economic and aesthetic perspectives can "live with" one another and be combined to actualize new ideas. As members of the organization increase their connective capacity though conversation and "reconceive what they're doing to include the other's work as part of their own" (Austin \& Devin, 2003, p. 103; italics in original), "yours" and "mine" are left behind, ensemble happens, and a coherent outcome that is "greater than the sum of parts" (Austin \& Devin, 2003, p. 131) can be realized.

In terms of the broader mission identified by Thompson et al. (2007), striving toward a more complete understanding of the inner workings of creative firms between "conception and consumption," our position is not, in our view, incompatible with other theorizing that has focused on identity (Gotsi et al., 2010), or creative slack (Cohendet \& Simon, 2007), or relational dynamics (cf. Courpasson, Dany, \& Clegg, 2011; Montanari et al., 2016), or synthesizing tensions to generate interim outcomes (prototypes, Harvey, 2014). The emphasis of our theorizing, however, has been on the importance of willfully maintaining a fragile, fallible form of sociality (Hjorth, 2014a, 2014b), an ongoing conversation that provides a requisite context for the successful combination of economic and aesthetic influence. We believe that it is important as well that our theorizing specifically addresses the distinctive characteristics of 
creative work, and that it draws from arts contexts to suggest conceptualizations that may yield broader understanding. Nuanced inferences about creative work arise more naturally, we submit, from thinking about conversation and ensemble than they do from existing piecemeal theories about creative work or frameworks developed in more generic (not specifically creative) contexts.

Based on our study, we suggest that leaders of a certain kind of organization - one that creates economic value by creating aesthetic value, aspires to highly differentiated outcomes, achieves "competitive advantage" because others cannot replicate its particular aesthetic appeal-must master the art of nurturing conversation. Such mastery may lead to attitudes and actions that seem at odds with guidance derived from existing theory: An open attitude towards "living with" opposing influences is more productive than, for example, installing safeguards (Eikhof \& Haunschild, 2007), or "blending" to produce a more mainstream offering that compromises artistic integrity (indirectly proposed by Glynn \& Lounsbury, 2005). Conversation requires special circumstances to be maintained. These include shared norms that maintain multi-voiced interactivity, shared insistence on relinquishing ownership (sovereignty over individual work), shared desire to maintain conflict rather than to eliminate it or resolve tensions, and shared belief in the importance of unity in outcomes. Leading this way requires a shared understanding of the importance of belonging for creative becoming and an appreciation for the possibilities of ensemble and the aesthetic coherence of resulting 
outcomes. Acquiring this mastery may be challenging for conventionally trained managers; based on our encounter with e-Types, however, we suggest that the way to successfully combining conflicting economic and aesthetic influences within creative firms lies in this direction. 


\section{References}

Amabile, T. (1998). How to kill creativity. Harvard Business Review, September-October, 77-87.

Austin, R. (2008). High margins and the quest for aesthetic coherence. Harvard Business Review, 86 (1), 18-19.

Austin, R. D., \& Nolan, R. L. (2007). Bridging the gap between stewards and creators. MIT Sloan Management Review, 48 (2), 29-36.

Austin, R. D., \& Devin, L. (2003). Artful making - What managers need to know about how artists work. Upper Saddle River, NJ: Financial Times Prentice Hall.

Bakhtin, M, \& Holquist, M. (Ed.). (1981). The dialogic imagination (C. Emerson \& M. Holquist, Trans.). Austin: The University of Texas Press.

Bakhtin, M. (1986). Speech genres and other late essays. Austin: University of Texas Press.

Boehm, A. (2004). Theoretical coding: Text analysis in grounded theory. In U. Flick, E. von Kardorff, \& I. Steinke (Eds.), A companion to qualitative research (pp. 270-275). London: Sage Publications.

Caves, R. E. (2000). Creative industries: Contracts between arts and commerce. Cambridge: Harvard University Press.

Christopherson, S., \& Storper, M. (1989). The effects of flexible specialization on industrial politics and the labor market: The motion picture industry. Industrial and Labor Relations Review, 42, 331-347.

Cohendet, P., \& Simon, L. (2007). Playing across the playground: Paradoxes of knowledge creation in the videogame firm. Journal of Organizational Behavior, 28, 587-605.

Courpasson, D., Dany, F., \& Clegg, S. (2011). Resisters at work: Generating productive resistance in the workplace. Organization Science, May 2011 (Published online ahead of print), 1-19.

Davis, H., \& R. Scase. (2000). Managing creativity: The dynamics of work and organization. Buckingham and Philadelphia: Open University Press.

DeFillipi, R., Grabher, G., \& Jones, C. (2007). Introduction to the paradoxes of creativity: Managerial and organizational challenges in the cultural economy. Journal of Organizational Behavior, 28, 511-521. 
DeSantis, A. D. (2001). Caught between two worlds: Bakhtin's dialogism in the exile experience. Journal of Refugee Studies, 14 (1), 1-19

Edmondson, A. C., \& McManus, S. E. (2007). Methodological fit in management field research. The Academy of Management Review, 32 (4), 1155-79.

Eikhof, D. R., \& Haunschild, A. (2007). For art's sake! Artistic and economic logics in creative production. Journal of Organizational Behavior, 28, 523-538.

Florida, R. (2002). The rise of the creative class: And how it's transforming work, leisure, community, and everyday life. New York, NY: Basic Books.

Glasser, B. G. (1978). Theoretical sensitivity: Advances in the methodology of grounded theory. Mill Valley, CA: Sociology Press.

Glynn, M. A. (2000). When cymbals become symbols: Conflict over organizational identity within a symphony orchestra. Organization Science, 11 (3), 285-298.

Glynn, M. A., \& Lounsbury, M. (2005). From the critic's corner: Logic blending, discursive change and authenticity in a cultural production system. Journal of Management Studies, 42 (5), 1031-1055.

Gotsi, M., Andriopoulos, C., Lewis, M. W., \& Ingram, A. E. (2010). Managing creatives: Paradoxical approaches to identity regulation. Human Relations, 63, 781-805.

Grabher, G. (2002). The project ecology of advertising: Tasks, talents and teams. Regional Studies, 36 (3), 245-262.

Guillet de Monthoux, P. (2004). The Art Firm. Palo Alto, CA: Stanford University Press.

Harvey, S. (2014). Creative synthesis: Exploring the process of extraordinary group creativity. Academy of Management Review, 39 (3), 324-343.

Haunschild, A. (2004). Employment rules in German theatres: An application and evaluation of the theory of employment systems. British Journal of Industrial Relations, 42, 685-703.

Heath, C., Hindmarsh, J., \& Luff, P. (2010). Video in Qualitative Research. London: SAGE. 
Hensemans, M. (2003). Social movement organizations: A metaphor for strategic actors in institutional fields. Organization Studies 24 (3), 355381.

Hesmondhalgh, D. (2013). The cultural industries. London: Sage.

Hesmondhalgh, D., \& Baker, S. (2011). Creative labor: Media work in three cultural industries. London: Routledge.

Hjorth, D. (2005). Organisational creativity: With Michel de Certeau on creating spaces for play (or heterotopias). Journal of Management Inquiry, 14 (4), 386-398.

Hjorth, D. (2012). Organisational entrepreneurship - An art of the weak? In D. Hjorth (Ed.), Handbook of Organizational Entrepreneurship (pp. 169-192). Cheltenham: Edward Elgar.

Hjorth, D. (2014a). Entrepreneuring as organisation-creation. In R. Sternberg \& G. Kraus (Eds.), Handbook of research on entrepreneurship and creativity (pp. 97-121). Cheltenham: Edward Elgar.

Hjorth, D. (2014b). Sketching a philosophy of entrepreneurship. In T. Baker, \& F. Welter (Eds.), The Routledge companion to entrepreneurship (pp. 41-58). London: Routledge.

Hoffman, A. J. (1999). Institutional evolution and change: Environmentalism and the U.S. chemical industry. Academy of Management Journal, 42 (4), 351-371.

Howkins, J. (2001). The creative economy: How people make money from ideas. London: Penguin.

Jeffcutt, P., \& Pratt, A. C. (2002). Managing creativity in the cultural industries. Creativity and Innovation Management, 11 (4), 225-233.

Johnstone, K. (1979). Impro: Improvisation and the theatre. New York, NY: Routledge.

Lakoff, G. (1993). The contemporary theory of metaphor. In A. Ortony (Ed.), Metaphor and Thought, 2nd Ed (pp. 202-251). Cambridge:

Cambridge University Press.

Levinas, E. (1981). Otherwise than being, or beyond essence (A. Lingis, Trans.). The Hague: Martinus Nijhoff.

March, J. G. (1991). Exploration and exploitation in organizational learning. Organization Science, 2 (1), 71-87.

Massumi, B. (2002). Parables for the virtual: Movement, affect, sensation. 
Durham, NC: Duke University Press.

Menger, P. M. (1999). Artistic labor markets and careers. Annual Review of Sociology, 25, 541-574.

Merriam-Webster. (2017). Converse. Online dictionary. Retrieved from https://www.merriam-webster.com/dictionary/converse

Miles, M. B., \& Huberman, A. M. (1994). Qualitative data analysis: An expanded sourcebook. Thousand Oaks, CA: Sage.

Montanari, F., Scapolan, A., \& Gianecchini, M. (2016). Absolutely free’? The role of relational work in sustaining artistic innovation. Organization Studies, 37 (6), 797-821.

Morgan, G. (1980). Paradigms, metaphors, and puzzle solving in organization theory. Administrative Science Quarterly, 25 (4), 605-622.

O’Donnell (now Hessel), S., \& Devin, L. (2012). Collective creativity: ETeams and E-TeamWork. In D. Hjorth (Ed.), Handbook of Organisational Entrepreneurship (pp. 280-299). UK: Edward Elgar Publishing.

O'Reilly, C. A., III, \& Tushman, M. L. (2004). The ambidextrous organization. Harvard Business Review, 82 (4), 74-81.

O'Reilly, C. A., III, \& Tushman, M. L. (2008). Ambidexterity as a dynamic capability: Resolving the innovator's dilemma. Research in Organizational Behavior, 28, 185-206.

Poulos, C. N. (2008). Accidental dialogue. Communication Theory, 18, 117 138.

Reay, T., \& Hinings, C. R. (2009). Managing the rivalry of competing institutional logics. Organization Studies, 30 (6), 629-652.

Rothbauer, P. M. (2008). Triangulation. In L. M. Givens (Ed.), The SAGE Encyclopedia of Qualitative Research Methods (pp. 893-894). Thousand Oaks: SAGE Publications.

Steyaert, C., Bouwen, R., \& Van Looy, B. (1996). Conversational construction of new meaning configurations in organizational innovation: A generative approach. European Journal of Work \& Organizational Psychology, 5 (1), 67-90.

Strati, A. (1999). Organization and Aesthetics. London: SAGE Publications Ltd.

Strauss, A., \& Corbin, J. (1998). Basics of qualitative research, 2nd ed. 
Sage, Thousand Oaks, CA.

Suddaby, R. (2010). Editor's comments: construct clarity in theories of management and organization. Academy of Management Review, 35 (3), 346-357.

Sutton, R. (2001). The weird rules of creativity. Harvard Business Review, 79, 94-103.

Thompson, P., Jones, M., \& Warhursts, C. (2007). From conception to consumption: Creativity and the missing managerial link. Journal of Organizational Behavior, 28, 625-640.

Townley, B. (2002). The role of competing rationalities in institutional change. Academy of Management Journal, 45 (1), 163-179.

Yin, R. K. (1984). Case study research: Design and methods. Beverly Hills, CA: Sage Publications. 